\title{
Det digitales paradigmer
}

Storbyen, hyperteksten og sindets storcentre ${ }^{\mathrm{I}}$

ANDREAs KitzmanN

Hvis jeg, som Salomon, ...

Kunne få mit onske opfyldt

mit onske. .. $O$ at vere en drage,

et symbol på himlens magt - af silkeormens storrelse eller enorm; til tider usynlig.

Lykelige fanomen.

Marian Moore ${ }^{2}$

Det at vare digital er anderledes. Vi venter ikke på nogen opfindelse. Den er her. Den ill her mu. Den er nesten genetist of Den fer forstact po don made, at hrer generation wh Nicholas Negroponte3

Indrømmet, det kan godt synes noget upassende at sammenstille Marianne Moores betagende begær ef er en kraftfuld selv-transformation med Negropontes opblæste profetier om en digital fremtid. Dog vil enhver undersøgelse af cyberkulturen uden for bestyrelseslokalet bekræfte, at sådanne lyriske fremmaninger af det digitale mere hører til reglen end til undtagelsen. Mens arsagerne til en sidn ensidis ortrettering of telnogien kalder pa bersidig portrotige

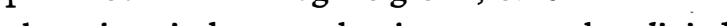
bekynring sig her on idet jeg ser som den digitale teknologis meget virkelige magt generelt betragtet, og hypertekstens mere specifikke magt til at påvirke og ændre nogle meget fundamentale aspekter ved den menneskelige erfaring. Som jeg vil formuler det i det følgende, så er sådanne fundamentale virkninger resultatet af paradigmatiske forskydninger mellem det teknologiske og det menneskelige - for-

PASSAGE 3I/32 - I999 skydninger som finder deres mønster i den menneskelige aktivitets daglige handlinger og udtryk

For at begynde min tentative udforsloning af en sa vidtrækkende påstand, vil jeg inddrage Andrew Feenbergs brug af udtrykket "teknisk kode“ " som en måde, hvorpå jeg kan indramme krydsfelterne mellem det kulturelle og det teknologiske:

Den teknologiske rationalitets dominerende form er hverken D ideologi (et essentielt diskursivt udtryk for sam fun his

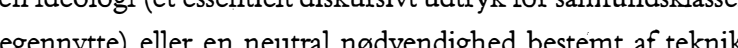

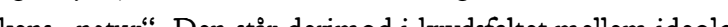

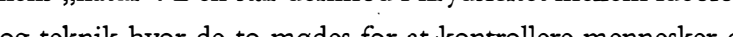
og teknik hvor de to modes for at kontrolere mennesker og ressourcer 1 overenstemmelse med det, jeg kalder "tekniske koder". Kritisk teori viser, hvorledes disse koder usynligt afle rer værdier og interesser $i$ regler og procedurer, planer og genstande og gør den dominerende ideologis jagt efter magt o fordele til en rutine. 4

Teknologien er derfor for Feenberg en „kampscene“, et „tingenes parlament, hvor civiliseringen alternativer bliver debatteret og besluttet". Fordi teknologien hverken er neutral eller uundgåelis kan den således bedre forstås som en konstellation af parigmer, verdier og teknikker, som bode genaf paradigner, vardier og tekniker, som bàde gento of

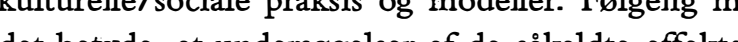
det betyde, at undersogelser af de sakaldte effekter af samfundets teknologi ikke bør beskæftige sig med en-dimensionale relationer mellem årsag og virkning men derimod med en fler-dimensional model bestående af social og kulturel indflydelse, hror tek- 
nologien blot er et enkelt medlem af en yderst forskelligartet gruppe af aktører.

Efter dette, vil jeg nu bevæge mig mod min påstand om den digitale teknologis "tekniske kode" og den - i det mindste vejledende - rolle i udformningen de sociale or kut de sociale og kajurer. En arbejdshypotese er her, at den digitale teknologi ud over at være en væsentlig motor $i$ den teknologiske udvikling i slutningen af det tyvende århundrede også er unik ved sin evne til at gennemtrænge og varierende grad transformere en bred vifte af teknologiske og kulturelle miljøer. En sàdan evne ka skyldes distinkte trak i den digitale teknologis definerende karakteristika. Disse karakteristika blive defineret ganske kortfattet og brugbart af Tony Feldman i hans Introduction to Digital Media.s De er kort som følger: 1) Digital information er manipulerbar 2) Digital information er tot [dene 3) Digita infortion 4) Digital information kan komprim
5) Digital information er upartisk

Den første bestemmelse henviser til den digitale form som værende ultimativt generisk, idet den kan realiseres på et utal af måder uden tab eller ødelæggelse af dens essentielle natur. Visuelle data er ikke forskellige fra tekstuelle data og de kan kombineres, beskæres, udvides eller om-organiseres ganske som man vil. For det andet betyder det, at den digitale information af natur kan behandles i netværk, a den samtidigt kan opleves af et stort antal brugere en potentielt global målestok. Netværket fungerer også som en intern model i forbold til organisaion ogsà som en intem mode $i$ forhold til organisation som de mest alminet gitale informations sakalde "tahed". henviser dens relative frihed fra materielle eller fysiske bindinger - en egenskab som fremhæves yderligere ved dens evne til blive presset sammen af særlige datakompressionssystemer. Det essentielle ved disse karakteristika er, at den digitale form fungerer ifølge love som er signifikant forskellige fra den naturlige verden. Tidslige og rumlige begrænsninger kan simpelthen ikke anvendes på det digitale pà samme måde som på det analoge. Endelig så refererer den digitale informations såkaldte upartiskhed til det faktum, at den digitale informations bærere eller agenter (dvs. computerne) er relativt ambivalente or for kode er digital kode ligegyldigt om dens endelige resultat er et billede, en arbejdsgang indledt af en Eotarm eller et konventionelt essay.

Efter at have reflekteret over det digitales specifikke træk som de defineres hos Feldman, vil jeg gerne her kort overveje muligheden af at se dem i en overført betydning, så de former et lignende antal mere generelle paradigmer, som fungerer som mulige modeller eller "tekniske koder" for individuelle, sociale og kulturelle relationer og praksiser. Ganske kort er de som følger:

I) Udvidelse/ forøgelse [augmentation]: hvor den i teknologien anvendes generelt, så er den type udvidelse eller forogelse der er mulis ved hislp af det digita digitale både fysisk transcer være digital beskrives ofte som at være mere end menneskelig - fx post-menneskelig eller cyborg. 2) Fragmentering: det ikke-lineære som det dominerende format for digitale rum, i ojeblikket eksemplificeret af World Wide Webs hypertekst. Den resulterende fragmentering har implikationer for udtryk, representation og i yderste konsekvens kognition.

3) Mutation: den sømløse „morphing“ af én tilstand over $i$ en anden udrydder enhver forestilling om autenticitet og muliovis endda fremgang eller udvikling Som sodan er den eneste konstant formdringen, som har utallige retninger.

4) Hyper-kontekstualisering: muligheden for en4) Hyper-kontekstalisening: muligheden for en-

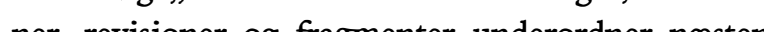
ner, revisioner og fragmenter underordner næsten fuldswig ind tydning fjernes derved fra budskabet og udgøres snarere af den evigt forandrende interaktion mellem kontekst og budskab.

5) anti-kropslighed: idet kroppen og tanken er udvidet eller forøget har tanken en tendens til at vinde til sidst. Kroppen er ikke tilpasset det digitales, kybernetikkens krav og lyster. Den er blot kød “", en primitiv overlevering fra den før-digitale fortid.

Det er på basis af disse indledende og indtil videre Deterte forudsetninger, at jeg og nil videre tilbage til

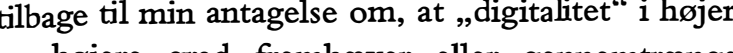
og hojer grad fremhaver eller gennemtrænger samfundets og kulturens praksiser og strukturer. Celia Lurys undersogelse af "protese-kulturen“" er en brugbar reference i denne sammenhæng. Her udforskes teknologiske forlængelser (proteser) som $\mathrm{fx}$ fotografiet på basis af deres indvirkning på opfattelse af og praktiseringer af selvets identitet og de kulturelle former, der dermed konstitueres. Selvom mange af Lurys ideer er parallelle med min egen interesse i digitalitetens proteselignende eller udvidende [augmenting] natur, vil jeg dog nu kun referere til hendes omskrivning af mimesis-begrebet via Benjamin og Taussig.

Det (mimesis) er beslægotet med det 'at gore sig selv magen til omgivelseme'; den 'natur som kulturen bruger til at skabe den anden natur, evnen til at kopiere, imitere, lave modeller, udforske forskelle' (Taussig, I993: xiii) ... Mere specifikt skal den mimesis som er involveret $i$ at se fotografisk forstås som noge der provokerer en kropslig mediering i umiddelbarhed, en mediering, som er både metamorfose og sammenfald. Det er en metonymisk relation, som både opererer inden for og uden for representationen, inden for og uden for rammen og har potentiale til at fremkalde en adskillelse af sanseme, som forstyrrer individets kohærens, da det er forbundet med sansninger som undviger reprasentationen. Tager vi først begrebet at 'gøre sig selv magen til omgivelorne' kan man sporge sig selv, hvordan sådan en idé kan anvendes $i$ en paradigmatisk forståelse af det digitale. I en bestræbelse på at fremskaffe en vis grad af specifikhed, vil jeg vende tilbage til eksemplet hyper-tekst, idet det er en af de primære realiseringer af de digitale paradigmer som er skitseret ovenfor og som sådan en instrumentel lraft konstruktionen af det såkaldte netværkssamfund. Derfor er det min påstand, at hypertekst og de forskellige påstande og diskurser, som hvirvler rund om den, også kan ses som havende en mimetisk funktion, der lige som Lurys eksempel med fotografiet ændrer 'individets kohærens' og hans/hendes rum inden for samfundets og kulturens matricer. modseming til fotografiet vedrorer effekten her dog verden in af virkeligheden. Derudover vil jeg hævde, at hyperteksten pga. dens tætte association med viden (som representeretgennem sproget) har yderligere betydning for de „,bevidsthedsmodeller“, hvorom subjektiviteten formes og praktiseres. Sådanne tanker er nogenlunde parallelle med Mark Posters teori om, at elektronisk medieret kommunikation medfører en „radikal re-konfigurering af sproget, og dermed konstituerer subjekter uden for det mønster, der dannes af det rationelle og autonome individ "7 Ifalge Poster signalere informationens modu" " [the mode of information] som den repres modus" [the Poderenteres af (dis. med tetsmodeller og den sociale orden, der struktureres rundt om dem. Pa samme måde vil jeg hævde, at hyperteksten kan hjælpe til med at artikulere et brud $i$ tiden, rummet og kroppens erfaringsmæssigt baserede orden. Som sådan indeholder hyperteksten som

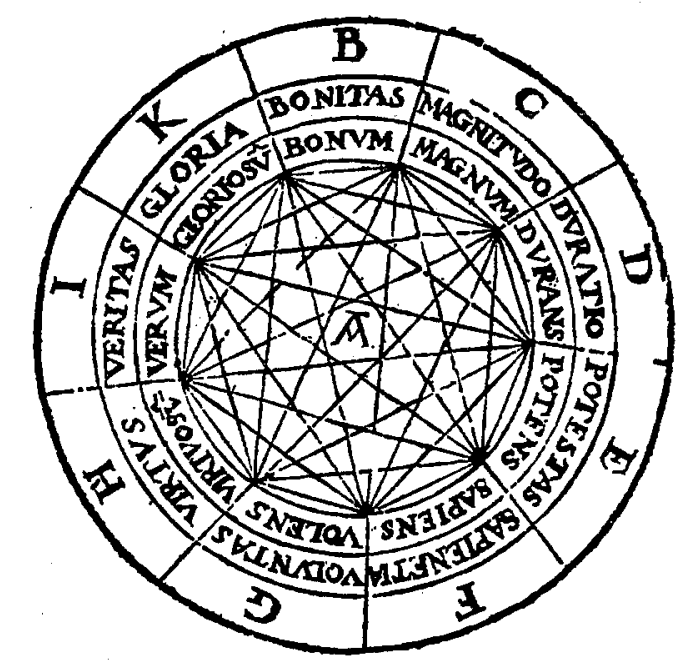

Figur 'A'. Fra RAsMond LurL: Ars brevis (Opera, Strassburg 60 Tr7). 
en specifik applikation eller teknisk kode i forskellig grad det digitales fem paradigmer, som nævnes ovenfor. På de følgende sider vil jeg kort skitsere et antal måder, hvorpå man kan „læese“ det hypertekstuelle i stedets, rummets og identitetens materielle orden

\section{Navngivning af hyperteksten}

Mange af mine påstande og .spørgsmål er baseret på en rudimentær definition af hyperteksten - et begreb som den selvudnævnte visionære Theodor Nelson skabte for at benævne ikke-lineære metode for organisering og tænkning. Som sådan er der ingen hovedtekst eller informationskilde, men ku links fra et element til et andet. Nelson benævnte dette hypertekstuelle rum „docuverse“, og det er det store hele sammenligneligt med World Wide Web. ${ }^{8}$

I tilfældet med de elektroniske netværk så omorganiserer hyperteksten tid og rum ved hjælp af ikkelineme a biente "knudepunkter [noles] og sier,

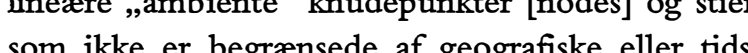
mom ike er begre for tid gan sol som folge deraf er de betingelser for tid og am, som bstemmer realtetene $i$ den fysiske erfaring, ikke langere sà vasentige $i$ cyberspace-landskabet. Der er gjort meget ud af dette i de seneste bøger, som er udgivet om den elektroniske kultur især i forhold til de mere utopiske påstande, som omgiver informationsteknologien. 9 Denne argumentation og dens dystopiske modpart vil jeg ikke diskutere i denne korte fremstilling. Det e langt mere frugtbart at se på den måde, hvorpå hyperteksten er blevet beskrevet som re-definerende rolleme og forholdet mellem forfatter og læser, eller mere generelt mellem designeren (eller den forste producent af indhold og kontekst) og brueren. te in

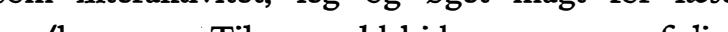
ren/hrugeren. Til gengald bidrager mange af disse beskrivelser til megen af den utopiske eller revolutionære hypertekstuelle diskurs, som repræsenteres af skikkelser som Michael Joyce, Stuart Moulthrop og som en af de ekstreme, Ted Nelson. Som oftes har sådanne påstande en vis ideologisk vægt, idet d bliver brugt til at forsvare hyperteksten over for den

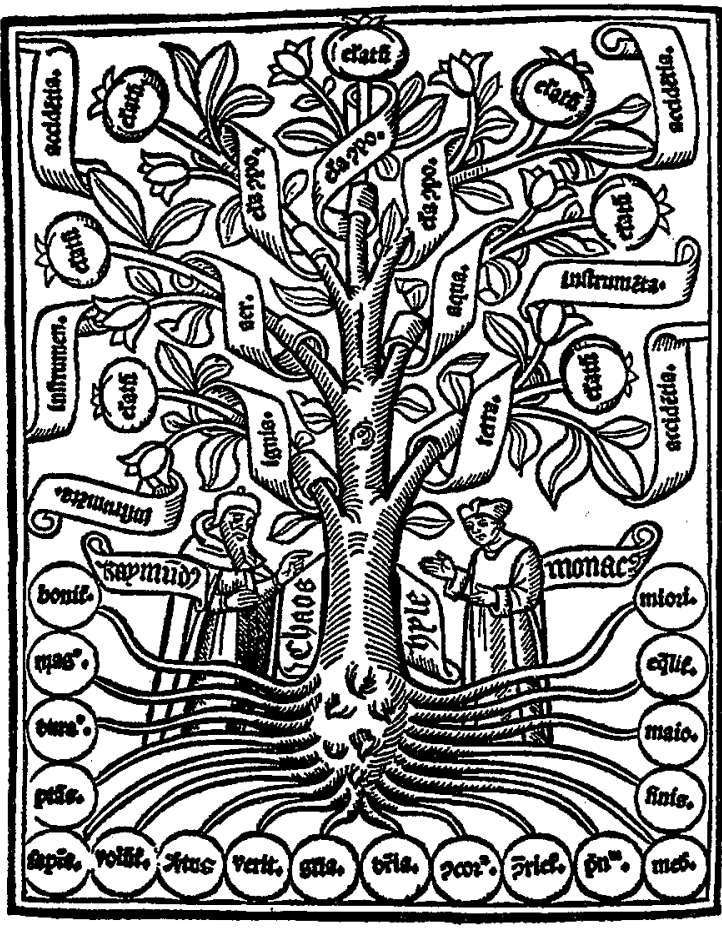

\section{RaYMoND Lurl: Arbor Scientia (ed. Lyon Ists).}

trykte kulturs såkaldte tyranni og dens rolle i skabelsen af den moderne stat. ${ }^{\text {To }}$ Hvor jeg bestemt deler den idé, at hyperteksten er et tegn på en tidsalder, der i stadig stigende grad er motiveret og struktureret af det digitales paradigme, er jeg ude af stand til at tage del $\mathrm{i}$ den lovprisning, som ofte følger disse observationer. Det er derfor jeg benytter Espen Aarseths kombinerede brug af begreberne kybertekst og ergodik som en måde, hvorpå man kan definere hypertekst.

Begrebet kybertekst fokuserer på den mekaniske organisering af teksten ved at se mediets finesser som en integreret del af den litterære udveksling. Det setter dog også fokus på forbrugeren eller brugeren af teksten som en mere integreret figur end selv receptionsestetetikken ville påstå. ... I den kybertekstuelle proces effektuerer brugeren en semiotisk sekvens, og denne selektive bevegelse er et stykke fysisk konstruktionsarbejde, som de forskellige opfattelser af „lesning“ ikke indbefatter. Dette fænomen kalder jeg ergodisk, et begreb jeg har hentet fra fysikken, og som stammer fra de greske ord ergon og hodos som betyder „,arbejde“" og „,tri“..1
Aarseths terminologi er her brugbar i det omfang, den understreger både den tekmiske konstruktion af hypertekstbegrebet og det karakteristiske ved brugerens rolle i og forhold til dets definerende træk og konstruktioner. Således passer terminologien mit eret anske om at forfolge de sporgsmil vedrarende get ten sten og mere generelt

I det folgende håber jeg at kunne frembringe nogle diskussioner om hypertekstens ( $o g$ det digitales) manifestationer $i$ hverdagslivets bevægelser, forhandlinger og konstruktioner. Disse diskussione skal dog ikke tages som et forsøg på at konstruer en slags evolutionær fortælling i forhold til teknologiens rolle i det menneskelige samfunds overordnede matrix. I stedet har jeg komponeret mine påstande omkring isolerede observationer og lokale refleksioner, som er et resultat' af næsten tilfældige og delvist styrede vandringer gennem historiens og kulturens ,passager".

\section{Hypertekstens sind og storby}

dringer bringer mig $i$ kontak med nogle aktuelle skjulte forbindelser mellem bevidstheden, byen, global økonomi og den hypertekstuelle organisering af cyberspace. En af hovedtankerne bag min interesse $i$ at kombinere sådanne elementer er den opfattelse, at urbane miljøer gradvist bliver „gen-forestillet" som „,ites“ inden for et økonomisk/elektronisk globalt netværk og at en sådan "gen-forestilling“" medførèr forandringer inden for de fysiske og mentale rum, i hvilke menneskeligt liv konstrueres" og erfares. Jeg burde nok her understrege, at disse anderstrege, at disse gen-forestillinger og konstruktioner llkke, arhundrede, men des i forstellge kulurer og histonise penoder. Saledes har både eksemplet med storcentrene [shopping malls] og ,befestning“, som jeg udforsker i de følgende, haft adskillige forgængere både på traditionelle bytorve og i gotiske katedraler. Hver af diss kan beskrives vha. begrebet „materialitet“, som det diskuteres i Thomas Kroghs nyligt udgivne bo Technology and Rationality; ${ }^{\mathrm{x} 2}$ et begreb, der „,kan de- fineres som den sociale virkelighed, som objekter produceret af menneskelig aktivitet besidder." Kroghs tilgang er her vigtig $i$ forhold til mine egne undersøgelser, pga. dens insisteren på at forbinde alle overvejelser vedrorende teknologi med eksempler på teknologisk udvikling af menneskelig effaing. For at vare me precis, ing. For at vare

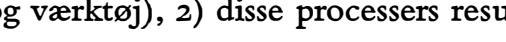
tater (produkterne), og 3) den sociale virkelighed, som skabes gennem en teknologisk proces. ${ }{ }{ }_{3}$ Denne definition bliver grundigt udviklet og problematiseret i løbet af Kroghs bog og som sådan benægtes den simplificering, som mit korte citat måtte give udtryk for. For at give en vis indikation af den deraf følgende kompleksitet vil jeg blot tilføje, at de tre pointer som jeg har antydet ovenfor, indgår $i$ et netværk af inter-relationer og indflydelser. Som sådan er blandingen af teknologi og menneskehed bundet til en dymamik, som det er umuligt at udrede eller observere $i$ en statisk form. Det bedste man kan gøre er at springe ud i strømmen og notere sig det, der kommer forbi.

Et godt eksempel er den opfattelse, at nutidens storbyer i stigende grad placeres i forhold til elektroniske landskaber for så vidt, at det hypertekstuelle paradigme, som $i$ høj grad bestemmer samtidens elektroniske rum, også begynder at influere de bymæssige miljøers form. Hvorvidt en by er vigtig afhænger derfor af dens deltagelse $i$ den globale økonomi og det globale netværk, der består af majoritetsbestemte flows af fysiske og elektroniske „data“, og som den kan fà adgang til fra adskillige punkter og platforme. ${ }^{44}$ Samtidig giver storbyen som hypertekst" også plads til at minoriteternes rum som hypertekst ogsa plads til at minoriteternes rum cos som i den hypertekstu-

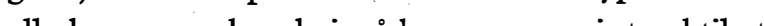
pol for tillu man mangler varktojet og den viden, der skal til for at Tencer er aldernative knuder "blot en mere end trusler mod den globale kulturs magt- 
strukturer. På den måde kan København have sit Christiania med dens anarkistiske besættere og hashcafeer, og kunder i New Yorks East Village kan indsnuse den spending det giver at gå rundt $i$ byen snuse den spand or sig til på Reeperbabn. Igen er det muligheden for vælge, der er vasentig at huse skabe forbindeser, at gà fra en zone til den næste, mens man søger efter nogle fa „bytes" med oplevelse og stimulans. Men hvad så med hyperteksten som model for sindet eller bevidstheden? Det, der er særligt væsentligt for mig i forbindelse med den øgede udvikling af de elektroniske netværk, er, at ud over at pàvirke såkaldte real-time-forhold og globaliseringen af økonomisk og social aktivitet, så er hypertekste også i stand til at fremkalde en bestemt ,vanetænkning". Med andre ord: fordi hypertekst-paradigme i højere grad gennemtrænger kommunikationsmiljojere gad ge on joenes strect cink ning [habits of mind. I sin bog thisille Rendevon hvor han skriver om fænomener som elektronisk skrift og informationsnetværk, observerer Wittig, det der er på spil i forhold til, hvordan de nye teknologier tages i brug, ikke er teknologierne i sis selv, men mere den vanetænkning, der ligger bag deres konstruktion og implementering inden for politiske, økonomiske og sociale kontekster. ${ }^{77}$ Dette signalerer et gensidigt forhold mellem ydre og indre virkeligheder, som i denne sammenhæng medfører, at netværket faktisk er indgået $i$ et transformativ forhold mellem sig selv og bevidstheden. ${ }^{88}$ Det måske blot en anden måde at udtryke, at specifikke mask bection mediefor (bon deres koresonden retoriske former, som igen skal ses $i$ forhold til de kulturelle samer, som is Sådanne tanker bliver ofte brugt $\mathrm{i}$ diskussionen or hypertekstens såkaldte „revolutionære" potentiale en teoretisk model, som man har lant fra blandt andet Elizabeth Eisensteins arbejde med trykkepressens indvirkning på sociale og politiske strukturer. Selvom sådanne referencer er interessante, så deler de en tendens til at portrættere hypertekst (og computeren generelt set) på en isoleret og deterministisk måde. M.a.o. placeres hyperteksten (og computeren) ofte $i$ en helteagtig belysning som fremskridte og forandringens fortrop, som pludseligt dukker op en dag, hvorefter verden er transformeret. En af virkningerne ved sådan et portræt er at fierne dislussionen om vore dages telmologi fra tiligere tendendoser, der dog inters delvist forbinder bevidsthedens strukturer (eller de strukturer som er givet tanken), repræsentationens og udtrykkets struktur og de kulturelle strukturer, der ligger bag størrelser som fx parlamenter, biblioteker, familier og storbyen. I tilfældet med hyperteksten er den væsentligste pointe så at sige, at den er tegn på den „vanetænkning“, som fremdriver de forskellige inkarnationer af tidligere og nuværende „netværkskulturer", hvad enten det drejer sig om religiøse relikvier, arkitektoniske stilarter, den seneste version af Windows eller placeringen af et nyt storcenter $i$ et tidligere, uonsket" kvarter 20 For at

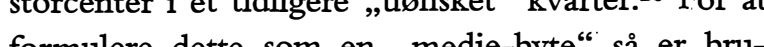
for gene like blot sneter, de nettet. Således hypertekst-sindet og de rum, som det
bygger.

\section{Erfaringer $i$ storcentret}

En af de mere etablerede og konkrete manifestationer af netværkskulturen og den globale økonomi er vor tids storcentre [malls] eller „de privatiserede økonomiske zoner", om man vil. De indikerer ikke blot forandringer i fællesskabets natur og nedgang $i$ „hovedgadens" økonomi, det er måske langt mere væsentligt, at de er en manifestation af det Stephen Graham og Simon Marvin identificerer som en ny (and Ger (rem for (a) Selvom Graham os

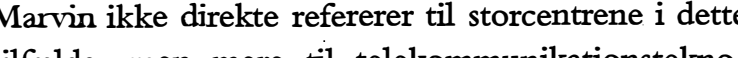
tilfalde, men mere til telekommunikationsteknologi, mener jeg dog, at observationen er anvendelig. For den effekt, der ligger til grund her, er den udstrækning $i$ hvilken det offentlige rum i stigende grad defineres inden for det globale okonomiske netværksparadigme. Et paradigme som tillægger lokale økonomiske eller sociale knudepunkter værdi forhold til deres forbindelse til det overordnede netværk. Som følge deraf fungerer vor tids storcentre (eller lignende privatiserede økonomiske zoner) som fysiske adgangspunkter, hvorfa forbrugerne an deltage $i$ de dominerende okonomiske forbrugsformer.

Velkommen derfor til storcentrenes virkelighed the malling of experience" - en eksperimentel zone, som stadig er „,lokal“, fordi den er placeret inden for et specifikt geografisk område, men som også er „æeterisk“ i den udstrækning, at „alle rum begynder at se ens ud og imploderer $i$ et kontinuum, mens tiden reduceres til besættende og tvangsbetonede repetitioner." ${ }^{22}$ Et "godt" center er derfor et der tilbyder alle de velkendte „links" - Benetton, Levi's, Virgin Records, Disney, Calvin Klein, Pepsi - og et genkendeligt interface - spiseområdet, kontantautomater, springvand, flere etager, rullende trapper, oplyste informationsskilte. Istanbul er derfor lige så god som Paris, som er lige så god som Vancouver og Bois. Man som . " on den "gode“ hjem tion. Fællesnæuneren er her vigtigheden af at være forbundet til hovedarerne pa en made, sa individuelle „platforme“ begrænset af sted, kultur, tid elle styresystemer ikke forstyrrer flowet.

Derfor skinnet af endeløse muligheder under en beroligende velkendt baldakin. Derfor beregninge og simuleringen af forskellighed der, hvor valget er ubegrænset, så længe det er ordentligt „linket“ Derfor en storcentererfaring, hvori rummet og erfaringen i stigende grad simuleres, emballeres og markedsfores, så det er let tilgængeligt oo klar til forbrug. Inen fremstår storcentret som elsemplarisk brug. Igen fer

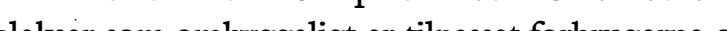
plekser som omhygeligt er thasset forbrugerne og den sociale elite, mens de udelukker de uønskede; „isolerede, urbane stødpudezoner som $x$ Bunker Hill i Los Angeles, Harbour Mace i Baltimore, Battery Park i Manhattan, ${ }^{23}$ Taksim i Istanbul, La Defence i Paris. Alle disse byplansregulerede område tilbyder en bred vifte af forlystelsespark-agtige oplevelser, som er bevidst adskilt fra det urbane livs mindre ønskede „realiteter“. Adgangen til disse er der- for begrænset til dem, der har det rette kodeord, ofte i form af et af de større kreditkort.

Befrestning

or at „indkøbsoplevelsen“ skal kunne fungere, er det nødvendigt at opbygge et antal tykke vægge og det nod bave adgang dem, der ike er heldige nok til a kan manifestere sig både overført og bogstaveligt overfort på den måde, at økonomiske barrierer be grænser adgangen ved hjælp af viden eller omkostninger, og bogstaveligt $i$ betydningen virkelige mure som for eksempel omkring elite kvarterer som Beverly Hills eller de indhegnede „samfund“, der breder sig som prikker i det forstadslandskab, som omgiver de større bymæssige centre. ${ }^{24}$ Sådanne barrierer kan måske bedst karakteriseres som fæstningssystemer sat op mod områder, som skiller sig ud, især de glemte eller fornæotede rum som er præo af svigt og uden for de borgerlice reticheders digned. Dete for lim. ighed Derte fum som rader, der ikke kan repareses eller astetiseres, eller omràder som simpelthen er "mindreværdige" pga etniske eller klassemæssige forhold. Ethvert bycentrum vælter i eksempler på disse, det være sig Brixton, Bronx eller selv den næsten eksklusive immigrantbefolkning, som bor i de utilitaristiske beboelsesblokke i den lille svenske by, som jeg nu bor i. Disse rum er defineret af minoriteternes identiteter og værdier, rum, som af den ene eller den anden grund ikke kan være blandt de væsentlige knudepunkter i nettet.

Sammenligningen mellem storbyen og computernetværk er her oplysende for så vidt, at den peger frem mod en genbearbejdelse af magtrelationer og den måde, hvorpå værdier (økonomiske og kulturelle) bestemmes og distribueres. En model med et center med dens fortid $i$ lineære hierarkier og samlebåndsmetodik er ikke længere af primær betydning. I stedet er sat netværket og dets ikke-lineare organisering af rum og ressourcer, hvor centret bliver "tabt" eller fragmenteret inden for et web af „knudepunkter“ [nodes] og „sites“ eller æteriske steder. Virilios begreb om den forsvindende by 
fanger et af elementerne ved at understrege de bymæssige (og sociale) erfaringers formløshed, fordi næsten alt bliver mærket som et muligt „forbindelsespunkt" inden for det globale nets æteriske spind.25 Dette fremkalder den velkendte remse on vigtigheden af rode forbindelser, hor vardi endm vigut ngang til af gode fortig at kunne folde lokle siturionen same og økonomi. ${ }^{26}$ Man kan ikke forestille sig noget værre end at være "rodfæste", at være uden fo strommen, at være fastast $i$ et rum med begrænsede muligheder og adgange. Man kan sige at dette er den sande fattigdoms moderne natur.

Men ikke alt er lige i netværket. Den højtbesungne påstand om netværkets essentielle demokrati (især med reference til Internettet) ignorerer den realitet, at den fysiske infrastruktur, som "huser" cyberspace, er klart bedst udviklet i de større urbane centre $\mathrm{i}$ de vestlige industrialiserede byer. ${ }^{27}$ Ydermere klumper adgangsportene til disse centre sig for mere kle fing for gerede økonosider i dyre kvarer eller or shing ningsverdenen. Derfor forbliver Timothy Learys fantasi om teenageren fra den indre by med en computer inden $i$ basketstovlen ikke andet end en fantasi - en lettere forvirret vision af en demokratis proces, som intet tegn viser på at blive realiseret.

Den velforbundne flanor

På trods af antydninger herom er denne artikel ikke ment som et slags paranoidt udråb om computerens ondskab. Det har nærmere været for at gøre opmærksom på, at de aktuelle udviklinger $i$ telekommunikation indikerer den digitale thologis para munikation interer den digite teknologis paravillet ind $i$ en vide viket ind iden videre udviling af de urbane centre og selve strikturen i den menneskelige tanke og udtryk. Hypertekstens rolle som et væsentligt eksempel pà det digitale paradigme fungerer her som den primære form for organisering og logik $i$ forhold til form og indhold. Der er med andre ord ku knudepunkter og forbindelserne imellem dem - en opfattelse som ikke kun beskriver elektroniske miljøer som World Wide Web men også fysiske miljøer såsom storcentre, turistmål, industriområder og store dele af væsentlige byområder. For at kunne "navigere" effektivt i sådanne rum er det tilrådeligt at tænke som hypertekst, hvilket vil sige, at man ska tillægge sig en „vanetænlming“, som opfatter det lokele mest i forhold til dets adgenge og relevans lokale mest i forhold til dets adgange og relevans og derudover a bevæge sig rundt $\mathrm{i}$ disse rum på en måde, der er parallel med "pege-klikke" metoden som bruges i leste elektroniske miljøer. En sådan vanetænkning tillader at lokale erfaringer kan påskønnes på basi af deres egne meritter, men med den underforståels at man altid kan vende „hjem“, hvis tingene blive alt for ukendte. Desuden har hvert lenudepunkt eller oplevelse forskellige parametre og niveauer, som „brugeren" har en betragtelig grad af kontrol over i det mindste i teorien. Man kunne i denne sammenhæng henvise til Club Med for så vidt, at selskabet tilbyder omhyggeligt konstruerede oplevelse til deres gester ved hjelp af højt stiliserede interfaces“ i inter ved hol "Ligeså gende A et speciet planlagt og afgram er større knudepunkt i den globale turismes netværk. Med sine gyselige markiser, som lover ubegrænse nydelse eller butiksvinduer med prostituerede, skaber det i sandhed plads til den perfekte hypertekstuelle oplevelse. Den „menu-drevne“ flanør med musen i hånden skal bare pege og klikke for at samle nye observationer og oplevelser. Disse oplevelser desuden potentielt subversive eller „farlige“ på det lokale niveau, men samtidig forbundet på en sådan måde, at de tillader et effektivt tilbagetog ind i de mere "normaliserede" knudepunkter i flertallets liv og opførsel. Således er nettets relative sikk og opførsel. Saledes er nettets relative sikkerhed. Den menu-

Det hypertekstuelle netværk fungerer derfor som en model, hvorved man kan artikulere den effekt som tendensen til øget globalisering har i forhold til økonomiske og kulturelle transaktioner og strømme. Det skal dog ikke forstås, som at der er en direkte forbindelse mellem hypertekst og $\mathrm{f} x$ indkøbscentre. Pointen er her nærmere, at hypertekstuelle netvær som $\mathrm{fx}$ World Wide Web på en eksplicit og måske overdreven måde udtrykker en række teknikker og en digital „vanetænkning“, som i stigende grad spiller en rolle i skabelsen af vor tids oplevelse af det urbane (og forstaden). Fordi hyperteksten i bund og grund er et kommunikationsmiddel, så har det ogsa betydning i forhold til fremtidice udtryks- og fremsillingsider. Det har yderligere betydning i forstlli hold il selve bevidsheden natur og i det omfan sproget og medier pavirker dens "konstruktion". Sådanne spørgsmàl ligger langt uden for denne artikels rammer, men de tibyder under alle omstændigheder nogle pejlepunkter for videre undersøgelser. For forståelsen af hypertekst som den dominerende måde, hvorpå netværk opstår og ordnes, giver os et redskab til eksplicit at forbinde såkaldte indre os ydre realiteter, som igen berører konstruktionerne af de mentale, sociale og fysiske rum, vi lever i. Med tanke på i hvor høj grad de nutidige urbane bylandskaber skabes af elektroniske magtlandskaber" kan sådan en forstålse af forbindelser nok være en nadvendig taktik til at foregribe vores skebe i not vendig taktik til
århundrede.

I sandhed et lykkeligt fænomen.

På dansk ved Bodil Hohwü Nielsen

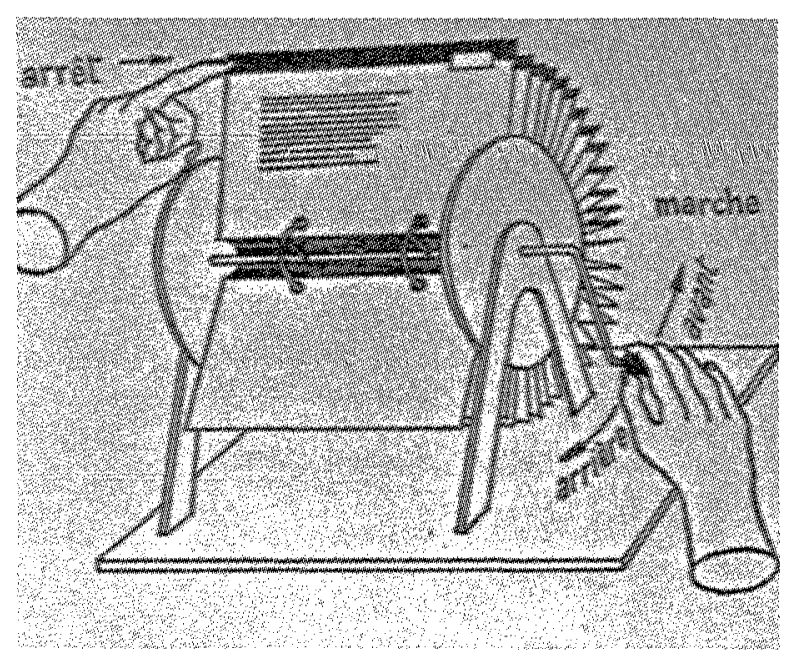

J.E. Fassio: Maskine til at lase Roussel, fra Bizare, nr. 3435 x964.
Noter

I. En tidligere version af denne artikel optreder i Convergence: the journal of Research in New Media Technologies, Autumn 1998

2. Moore, Marian: The Norton Anthology of Literature by Women: The Tradition in English, Sandra Gilbert and Susa rsir.

3. Negropo Andrew. Critical Theory of Technology. Oxford: Oxford University Press, r99r, p. I 4

5. Feldman, Tony: Introduction to Digital Media, London Routledge, 1997, p.

6. Lury, Celia: Prosthetic Culture: photography, memory and culture, London: Routledge, 1998, p. s.

7. Poster, Mark, The Second Media Age, Cambridge: Polity

Press, 1995, P. 57 .
8. Ud over at have en hang til at danne syllogismer folte Nealison en nærmest manisk eufori for sit projekt med at være et projekt, som ville indeholde hele verdens litteratur inden for et enkelt web af ,hyper-forbundne" dokumenter og endnu vigtigere var det, at det ville udfore en slags ,,revolution “ af selve bevidstheden. Karakteristisk er fx denne kommentar fra Nelson: ,Jeg onsker en verden, at lede efter de fysiske bor. sigt papirar ifo skabe og dele vores frembringelser uden privat at skulle fremskaffe og passe fysisk på dem. Der er et velkendt, altomfavnende motto, den jingle som vi alle kender fra den dag skolen er slut og som jeg tager ganske seriøst: „No more pencils; no more books, no more teacher's dirty looks." The Fantic Age (fra Computer Lib/ Dream Machines. Self-published, r974. Se ogsá Literary Machines: Swathmore: Self-published, 1991) Ligeså informativt er Nelsons http://www.sensemedia.net/849 9. Nogle af de mest vedholdende og udtalte „proklamationer" vedrørende hypertekstens revolutionære aspekter kan findes blandt forskellige personer tijknyttet Brown University og hypertekst-udgiveren Eastgate Systems. Se fx Georg Landows Hypertext: The Convergence of Contempo-
rary Critical Theory, and Technology, (Baltimore: John Hopkins Press, 1992), Michael Joyces „Notes Toward an Unwritten Non-linear) Hectronic Text (Psstmodem Culture, v.2 n. I, Sept 1991) Jay Bolters Writing Space: The Computer, HYpertext, and the History of Writing (Fairlawn, NJ:
Lawrence Assoc., rg9o) Man kan komme i forbindelse med Eastgate Systems on-line katalog via http:// www.eastgate.com/. 
ro. Se Mark Poster for yderligere undersøgelse af dette tema.

Ir. Aarseth, Espen: Cybertekst: Perspectives on Ergodic Literaure, Baltimore: the Johns Hopkins UP 1997, p. I.

nality. Aldershot: Ashgate, 1998, p. 5-6.

4. Stephen Graham og Simon Marvins nye bog Telecommunications and the City: electronic spaces, urban places (London : Routledge, 1996) fremskaffer længe savnet empirisk data om og analyser af den vækst, der er sket $i$ „cyberspace " $i$ forhold til andre sociale og $\varnothing$ okonomiske faktorer Med hensyn til de storre urbane centres rolle i udviklingen af cyberspace argumenterer Graham og Marvin, a

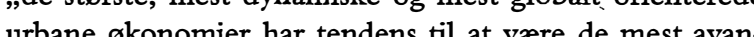
cerede, når det kommer til araden af udvikling drifssikkerhed, konkurrencedyotighed, sofistikerethed af deres telekommunikations infrastruktur og byens okonomisk og sociale gruppers brug af avancerede servicer" (p. I3r). Is. Der er dog forsøg på at undergrave og problematiser selve nettet. Finlands $M U U$ organisation har et antal interessante projekter og links. Gruppen „Media Filter“ særlig provokerende. Se http://muu.lib.hel.fi/Muu/ $/ \mathrm{Pa}_{\mathrm{a}}$ ges/muuorg.htm

en service som tilbyder informatio m nesten alle storre byer $i$ verden (http: $/ / \mathrm{www}_{\text {city }}$ i (og måloruppen for) denne service: Christianshavn. område syd for city og adskilt derfra af den indre havn. Den ene del af Christiania er blevet kendt som et center for den frie tanke og sommetider som et fristed for bortløbne og stofmisbrugere. Besøgende vil føle sig velkomn năr de spadserer rundt om dagen, men kan måske føle sig lidt utrygge om natten, når det bliver lidt vildere. Advar-

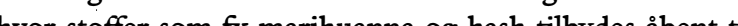
sal. “ Lige so signde er hiemmesiden for Amsterdms bordelkvarter. (http://www.imco.nl//)

17. Wiggig, Rob: Invisible Rendevouz: Connection and Collaboration in the New Landscape of Electronic Writing. (London: Wesleyan UP, 1994).

18. Sådanne emner udforskes i Michael Joyces seneste bog Of Two Minds: Hypertext, Pedagogy and Poetics, udgivet a University of Michigan Press, 1995. Pa forlagets hjemmeside kan man finde et uddrag af bogen: http://www Charge: Com anmications and Cultural Tras an Agent of Early-Modern Europe (Cambridge UP, 1980). Dette store værk er ofte blevet citeret for at placere hypertekstens potentielle påvirkning som en parallel til trykpressens. For eksempel beskriver Eisenstein opfindelsen og udviklingen af typografien som en af de væsentligste kræfter i standshingen af den „lingvistiske drift" på en mâde så den „,båd berigede og standardiserede sprogene og banede vejen for "uropriske sprog" ( $\mathrm{P}$ I europæiske sprog" (P II7).

og Marvin: „At konkurrere nye bymessige entrtive urbane billeder er centralt i den mediestrom bliver derfor brugt til badde at stotte denn konkurrencesituation og til at forsvare den fysiske genskabelse af bycentre $i$ overenstemmelse med postmodern tendenser: at forbedre 'produktet' for den globale medie 'markedsplads' ved at skabe fodgængertorve; kosmopolitiske kulturelle faciliteter, festivaler, 'spektakler'. os spors- og mediebegivenheder.

23. Boyer, p. 142

24. Et relateret fenomen er CIDs eller „, common interest development zones", som basalt set er samfund, som er konstrueret omkring specifikke sociale og økonomiske parametre. I følge nogle er dette fremtidsbølgen for så vid angår amerikanske byer og forstander - „Vi fremskaffer den nodvendige teknologi for at holde 40.000.000 amerikanere som bor 1 Common Interest Real Estate Developpistond, som kan findes pa hep 25. Virilio, Paul, „The overexposed city.““ Zone I (2), pp I4-3i.

26. Her bliver jeg mindet om et citat fra Umberto Ecos' roman Foucaults Pendul: ,ingen oplysninger er bedre end andre, tricket ligger $i$ at registrere dem alle sammen og sa lede efter forbindelserne. Der er altid forbindelser, na bare man onsker at finde dem." Eco, Umberto, Foucauls

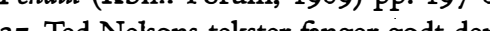

. mange, som ser internettet som et redskab for ytringfrinhed oo of Cyberspace" som et nyere eksempel kan man finde http://www.clas.ufl.edu/anthro/crberanthro/decl-indep.htm

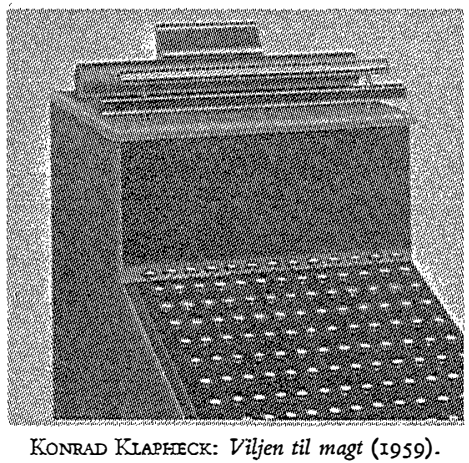

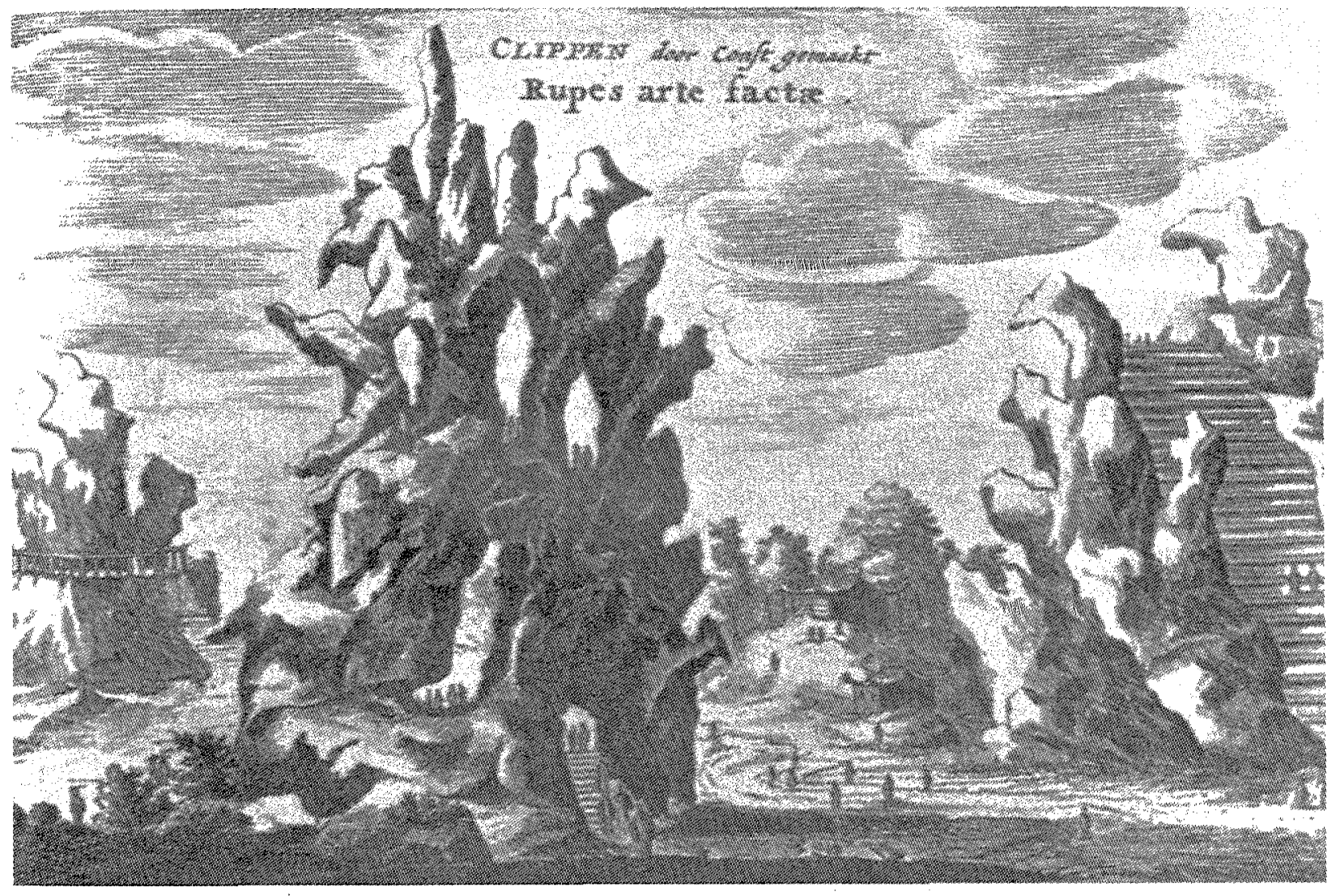

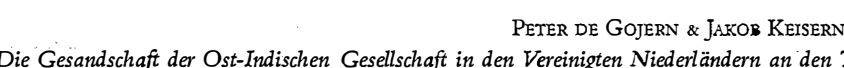

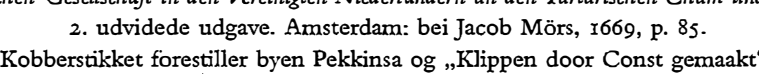

